Historic, Archive Document

Do not assume content reflects current scientific knowledge, policies, or practices. 



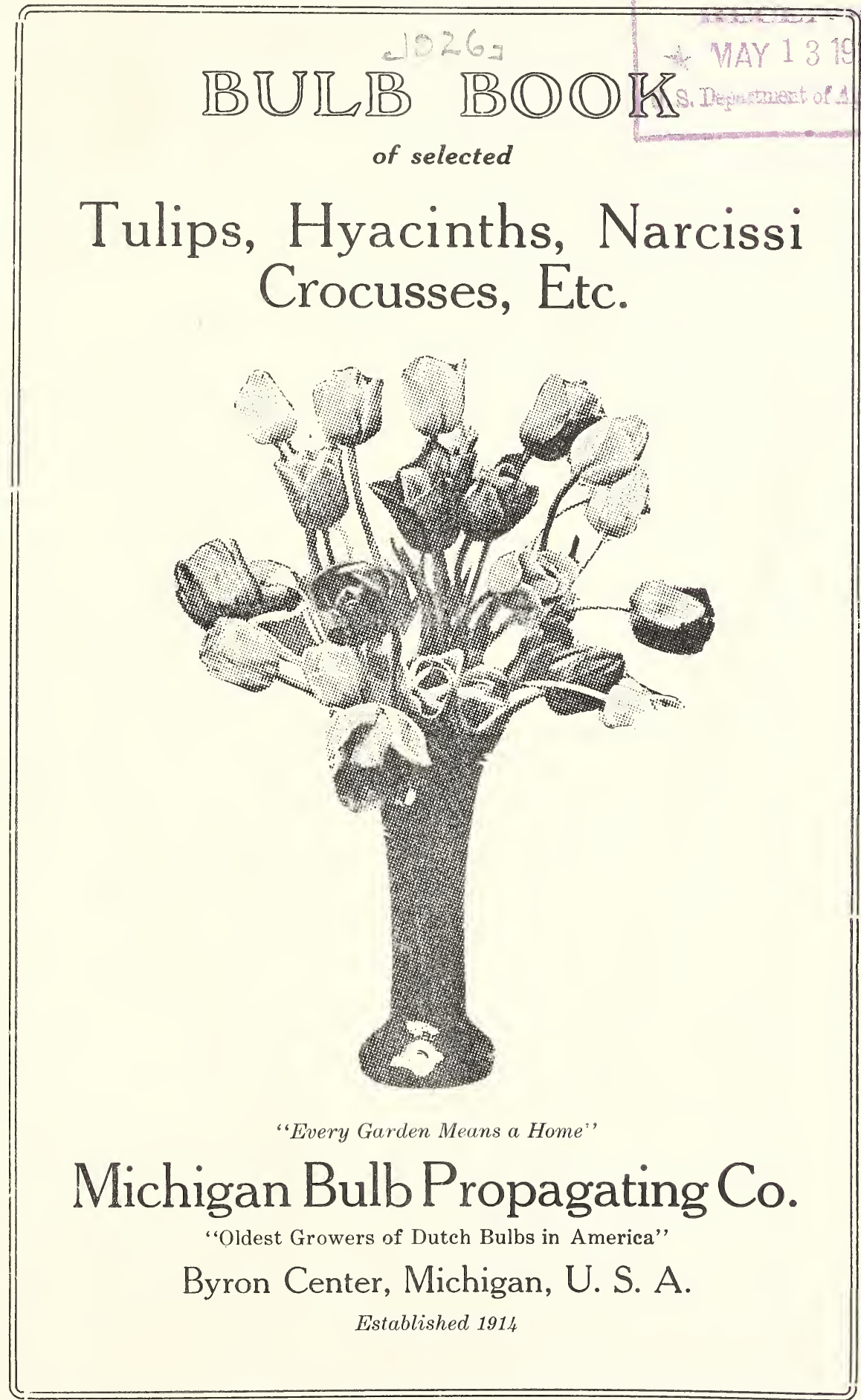




\section{FROM GROWER TO CONSUMER}

,All bulbs offered in this list are the products of our own Nurseries, located at Byron Center, Mich. All flower lovers should make it a point to visit us at any time during April or May, when our acres of tulips, Hyacinths, etc. are in full bloom.

Exact location of our" farm $/$ is seven miles south "of the city of Grand Rapids. To reach farm. by auto, take Division Avenue, Division Road, or M 13, and continue seven miles straight south.

"Carlisle Road" is a station on the Kalamazoo-Grand Rapids Division of the Michigan Electric Railway Company. All local trains' stop' at this station, which is a two minute walk from our farm. Busses operating between Grand Rapids and Kalamazoo, will aischarge or take on passengers at the front gate of our nurseries. We will at all times be glad to show visitors about the place, whether they wish to purchase bulbs or cut flowers or merely wish to took around.

\section{SELECTED, MICHIGAN GROWN HYACINTHS}

Our hyacinths have been carefully selected both for their hardiness and for their color quality. We offer them in two sizes, medium and large size. The first we recomend for bedding purposes and the latter for indoor culture. NOT'E: Planting instructions are sent with each shipment of bulbs, by carrying out the few simple rules our bulbs cannot fail.

No. 1. GERTRUDE, deep rose, placing it amongst the fiinest of

Doz.

$\$ 00$ pink shaded hyacinths

SECOND SIZE

No. 2. KING OF THE BLUE, large dark blue, almost purple ...FIRST SIZE

SECOND SIZE

No. 3. KING OF THE YELLOW, this sure is the king of the yellow varieties, large well filled spike.

....FIRST SIZE

SECOND SIZE

No. 4. LA VICTOIRE, brilliant red, solid spike FIRST SIZE

SECOND SIZE

No. 5 L'INNOCENCE. The most pure white hyacinth without a stain FIRST SIZE

SECOND SIZE

No. 6. LADY DERBY. Lovely fiesh pink, fine spike of waxy bells FIRST SIZE SECOND SIZE

$\$ 2.00$ 1.50 $\$ 15.00$ $\$ 2.00$ $\begin{array}{ll}1.50 & 10.00\end{array}$ $\$ 15.00$

No. 7. QUEEN OF THE BLUE. Deserving of the name, fine light blue with silvery appearance FIRST SIZE

SECOND SIZE FIRST SIZE

1.50 10.00

No. 8. MIXED in the above colors SECOND SIZE

\section{MICHIGAN GROWN TULIPS}

Tulips are our specialty, we grow acres and acres of them. For best results they should be planted before the middle of November. The letters E M. and L., following each variety indicate their relative earliness of blooming. $\mathrm{E}$ indicates Early; M, Medium; $\mathrm{L}$, Late, although, with fewi exceptions, most varieties bloom about the same time when planting outdoors, the late ones coming into bloom when the early ones are fully out. The figures indicate the height in inches. NOTE: Planting instructions are sent with each order. G. F. I. Means good fort indoors.

\section{SIX LEADING VARIETIES FOR INDOOR OR OUTDOOR CULTURE}

No. 9 LA REINE, M 12. White shaded pink when in full bloom. One of the most popular for forcing of bedding

Doz.

No. 10. YELLOW PRINCE, M 12. Clear golden yellow with narrow red fringe, splendid for forcing and bedding

$\$ 0.55$

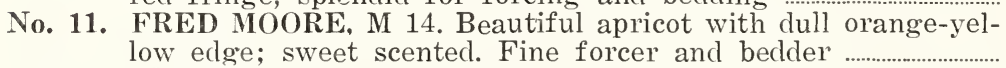

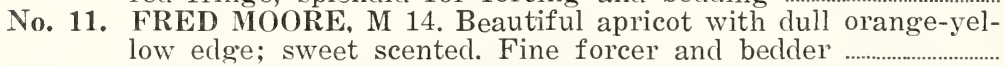

No. 12. CRIMSON BRILLIANT. M 14, Dazzling scarlet, inside glitering crimson. Tall flower, bedder and forcer

No. 13. POTTEBAKKER-WHITE. E 12, Good forcer and fine bedder, it's nure white color is unsurpassed

No. 14. ROSE GRIS DE LINE M 11. Vivid rose. This is considered one of the best in the pink varieties, forcer and bedder 


\section{SPECIAL OFFER OF THE PRECEDING SIX VARIETIES}

No. 15 Five bulbs each of the six varieties (30 bulbs) ...............................................................\$ 1.65

No. 16. Ten bulbs each of the six varieties ( 60 bulbs) .............................................................. 3.00

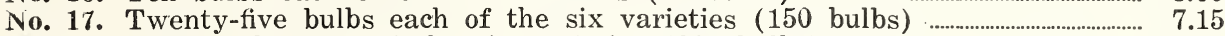

No. 18. Fifty bulbs each of the six varieties ( 300 bulbs) ………............................................... 13.50

No. 19. Hundred bulbs each of the six varieties (600 bulbs) ............................................ 25.00

\section{GENERAL LIST OF SINGLE EARLY TULIPS}

No. 20. ARTUS, L 10., Bright red, Liberty bell shaped flower. strong stiff stem. Fine for bedding or borders. No forcer

Doz。

100

No. 21. PRINCE OF AUSTRIA, M 14. Rich orange-scarlet G. F. I. or bedding, the large sweet-scented flowers are born on tall strong stems, great lasting qualities

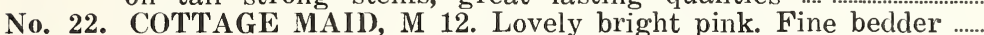

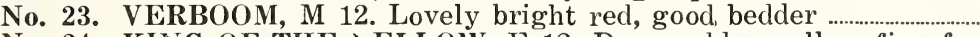

No. 24. KING OF THE Y ELLOW, E 12. Deep/ golden yellow fine for forcing and for cut flowers, also for borders

No. 25. PINK BEAUTY, L 13. Beautiful cherry rose, with white stripe

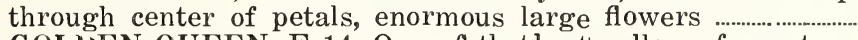

No. 26. GOLUEN QUEEN, E 14. One of the best yellows for pots ..................

No. 27. DIANA, M 11. Pure white strong stem. G. F. I. or bedding......................

No. 28. CARDINALS HAT, L 9. Peculiar red shaped flower...............

No. 29. QUEEN OF THE WHITES, L 10. snow white, fine for bedd.ng

No. 30. PROSER-PINE, E 12. Rich silky carmine rose strongly reccommended for forcing and bedding

No. 31. KEIZERKOON, E 16. Bright crimson scarlet with a deep yellow edge. large flower and good forcer

No. 32. WHITE BIRD, M 11. A neat looking tulip, dainty white ............

No. 33. BACHUS, E 11. Dark red, almost maroon, fine for forcing ......

No. 34. GOLD FINCH, L 12. Bright yellow, sweet scented, G. F. I. .......

No. 35. MRS. CLEVELAND, M 12. Beautiful light pink, lovely shaped

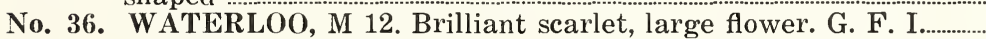

No. 37. COULEUR CARDINAL, L 12. Bright crimson scarlet, like

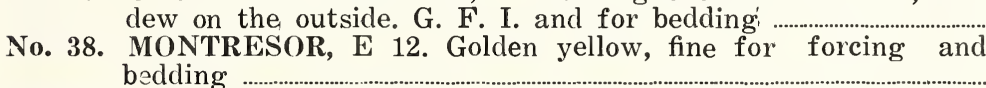

No. 39. PRINCE DE LIGNEY, M 16. Deep yellow flower on long stem

No. 40. WHITE SWAN, L 15. Pure white, egg shaped flower, fine for bedding and cutting

No. 41. GRAND MIXTURE, picked at random out of above colors for bedding and cut flowers only

\section{DOUBLE EARLY TULIPS}

Double tulips are very elegant in form, and very fine for borders and beds. Varieties indicated with G. F. I. may be forced though the work should be done slowly, they should be planted outdoors before the later part of November.

No. 42. MA COUSINE, M 12. Deep violet, one of the finest for

No. 43. MURILLO, M 12. Delicate pink, G. F. I.

Doz.

100

No. 44. VUURBAAK, M 11. Brilliant scarlet fine for bedding, G. F. I...

No. 45. VIRGULIUS, E 10 . Vivid pink, fine bedder

No. 46. COURONNE'D OR. Golden yellow flushed orange red G. F. I....

No. 47. -IMPARATOR RUBRORUM, M 13. Rich scarlet, fine bedder G. F. I.

No. 48. LA CANDEUR, L 12. Pure white, fine for bedding

No. 49. COMPACTA ROSEA, fine deep pink. G. F. I. and bedding .......

No. 50. RUBRA MAXIMA, E 12. Brilliant red, fine bedder and G. F. I.

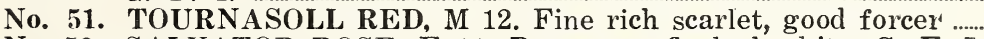

No. 52. SALVATOR ROSE, E 11. Deep rose flushed white, G. F. I. and bedder

No. 53. GLORIA SOLIS, E 11. Beautiful red, gold border, fine bedder... 
No. 54. TOURNASOLL YELLOW, M 12. Bright yellow and G. F. I.

No. 55. SLPERFINE MIXTURE of the above colors, fine for

Doz. bedding

\section{PARROT TULIPS}

Thel petals of these tulips ara fringed at the edge, and they are very peculiarly marked and feathered, resembling before opening a perrot's neck. They grow about 16 inches tall and should not be corced, plant any time during October and November, bloom in Mas.

Doz. 100

No. 56. ADMIRAL DE CONSTANTINOPLE, red flower with orange point

No. 57. CRAMOISI BRILLIANT, large deep carmine.

$.65 \quad 4.25$

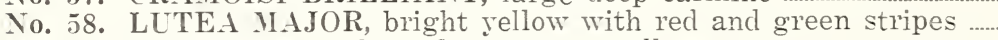

No. 59. PERFECTA, red marks on pure yellow petals

No. 60. IIARKGRAAF O. BADEN, yellow with green and scarlet stripes

No. 61. Five each of the above 5 varieties ( 25 bulbs)

No. 62. Ten each of the above, varieties ( 50 bulbs)

No. 63. Twenty-five each of the above 5 varieties (125)

5.25

\section{GIANT DARWIN TULIPS MAYFLOWERING}

It is our belief that we carry the most complete and finest collection of darwin tulips ever offered to the public. They do not force well, but never fail when planted outdoors in beds or borders, they are admirable for cut flowers.

\section{FIGHT DISTINCTIVE GIANT DARIVIN TULIPS}

\begin{tabular}{|c|c|c|}
\hline No. 64. CLARA BUTT, a fine pink for outcloor planting, 22 inch .... & $\begin{array}{l}\text { Doz. } \\
\$ 0.60\end{array}$ & $\begin{aligned} & 100 \\
\$ 4.25 & -10\end{aligned}$ \\
\hline 6. 65. PRIDE OF HAARLEM. Briliant rose carmine, witi dull blue & rot & \\
\hline 66. INGLESCONBE YELLOW. Really a cottage tulip but may be & & \\
\hline $\begin{array}{l}\text { planted with darwins. Glossy canary yellow ....................... } \\
\text { o. 67. WHITE QUEEN. Opening pale rose and turns almost pure }\end{array}$ & .60 & \\
\hline white when in full bloom, fine for border work & & \\
\hline 68. LA NOIR. The blackest of all tulips, large flower & & \\
\hline $\begin{array}{l}\text { o. 69. MARGARET (Gretchen). Outside clear pink, inside very soft } \\
\text { pink, with white base surrounded with faint blue circle }\end{array}$ & & \\
\hline $\begin{array}{l}\text { o. 70. DREAII. Pale heliotrope inside deep violet, } 25 \text { inch .............. } \\
\text { o. 71. BARRONE DE LA TONNAYE. Bright rose margines blush }\end{array}$ & & \\
\hline & .60 & \\
\hline $\begin{array}{l}\text { s }(40 \text { bulbs }) \\
(80 \text { bulbs })\end{array}$ & & \\
\hline tulips (200 bulbs) & & \\
\hline & & \\
\hline
\end{tabular}

\section{GENERAL LIST OF MICHIGAN GROWN DARWIN TULIPS}

Doz.

No. 76. HIPOLYTE. Violet blue large flower on strong stem ........... $\$ 0.65$

No. 77. PAINTED LADY. Creamy white, faintly tinted with pink should ba planted in cool and shadowy place

No. 78. IIR. FRANCOMBE SANDERS. Bright cocheneal, with white base

No. 79. PHYCHE. Silvery rose, edged soft rose. Large handsome flower with pala b?ue base, graceful stem

No. 80. HARRY VEITCH. This is a surprise color, brownish red is as near as we can get to it. 26 inch

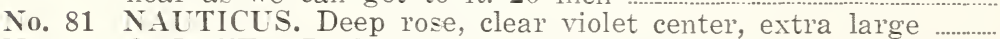

No. 82. GALATEA. Dark carmine rose. 26 inch

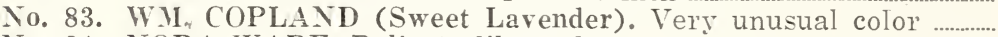

No. 84. NORA WARE. Delicate lilac color

No. 8.5. WM. PITT. Very dark crimson, shading to purple, white base starred dull blue

No. 86. ANNA. Deep flaming pink, inside somewhat lighter

No. 87. MADAME KRELAGE. Bright lilac-rose color, margined pale 
silvery rose, 28 inch

No. 88. BARilGON. Dazzling crimson, pure white base, ring deep blue

No. 89. THERESIA SCHWARTS. Rose lilac. Fine flower.

No. 90. MASSACHUSETTS. Most vivid pink, edged rose white, suburb large flower on strong stem

No. 91. WEDDING VEIL. Blush white, lilac shaded

No. 92. LANDELLE. Flushed vivid rose

No. 93. ...LANTERN (Nisa). Creamy white, shading to pink

No. 94. LA TRISTESSE. Dull slaty violet, inside dark blue with yellow tinged base, very distinct color

No. 95. FLAMINGO. Delicate shell pink, pointed flower on strong stem

No. 96. REV.EWBANK. Lilac mauve, shading to silvery hiliotrope .......

No. 97. PHILIP DE COMMINES. Deep brilliant mahogany, with purpple base, large flower

No. 98. MAJOR MASON. Beautiful soft rose

No. 99. KING HAROLD. Large flower of a glossy mahogany red ..........

No. 100. MRS. STANLEY. Silvery purplish rose with pale rose edge b'ue base, large flower

No. 101. VIKING. Large purple flower on strong stem.

No. 102. GRAND MIXURE. Including all the above colors

.60

4.00

\section{MAYFLOWERING OR COTTAGE TULIPS}

Though somewhat shorter in stem than the darwins, this class of tulips is highly reccommended for bedding. Especially where close planting is wanted. They comprise nearly all colors, are excellent forl cut-flower work and may be planted during October or November.

\section{WE START WITH THE SIX LEADING VARIETIES}

No. 103. PICOTEE' (Maiden's Blush). White margined, deep rose suffusing the whole flower as it ages, pointed petal

Doz.

100

No. 104 INGLESCOMBE PINK. Soft rosy pink changing into deep roso when in full bloom, large globular flower

$\$ 0.60$

No. 10 .

BOUTON'D OR Golden yellow with b'ack anthers 19 in.

No. 106. CALADONIA. Orange scarlet; large flower on strong thick $\mathrm{s}^{+} \circ \mathrm{m}$. fin for cut-flowers or beddings

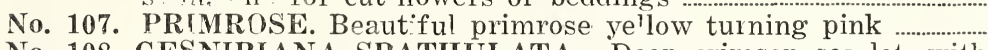

No. 108 GESNIRIANA SPATHULATA. Deep crimson scarlet, with bright b'ue base, enormous large flower

No. 109. Five of each of the above six varieties (30 bulbs)

No. 110. Ten each of the above six varieties ( 60 bulbs)

No, 111. Tw?nty-five each of the above six varieties (150 bulbs)

\section{GENERAL LIST OF MAYFLOWERING TULIPS}

No. 113. LA MARVEILLE. Orangei scarlet, flushed rose. Long beautiful shanad flower, with yellow center

Doz.

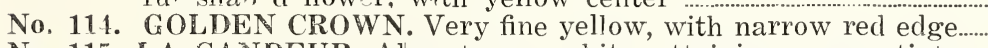

No, $115 \ldots$ LA CANDEUR. Almost pure white, attaining a rosy tint .......

No. 116. ORANGE KING. This is one of the largest Mayflowers, deep orang?, inside deep orange scarlet, with yellow base .........

No, 117 THE FAWN. Pale rosy fawn, changing into blush rose, large $\rho g g$ shand flower on a graceful stem

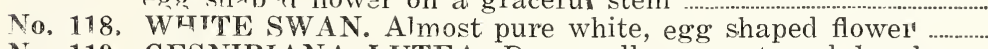

No. 119. FESNIRIANA LUTEA. Deep yellow, erect and handsome flower. Esnocially recommended for beds and borders

No, 120. ROVAL WH'TE. Beautiful white with primrose petals

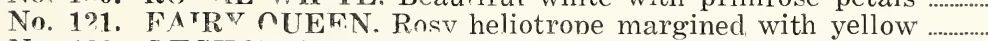

No. $19 \%$, EGHORN BONNET. Pale yellow elegant appearing flower

No 1 . Wr. forcing

No. 125. YELT OW FL PSH. Yellow large flower, fine forcer .....................

No. 196 . INGTESCOMBE SCARIET. Searlet flower 


\section{FREEDER TULIPS (MAY FLOWERING)}

This class of tulips has become very popular in recent years, the most unusual colors in Tulipdom are to be found in this class. They compete in height with the Giant Darwins. Planted in October and November.

No. 128. ASPACIA. Dull wine red, very large flower

Doz.

No. 129. BRONZE QUEEN. Soft buff inside golden bronze, yellow base

No. 130. CHESTNUT. Chestnut' brown, inside deep mahogany

No. 131. JAUNNE 'D OUEFF (Sun Rise). This is one of the most popular for borders or bedding, lively apricot color, with broad stripe of lilac, inside golden bronze, green base

No. 132. LA SINGULAIR. Opening silvery white, flushed deep purple

No. 133. CARDINAL MANNING. Dull wine red, flushed rosy orange turning into bright violet, shaded bronze

No. 134. YELLOW PERFECTION. Light yellow bronze, golden edge

No. 135. MEDEA. Large flower,strawberry colored brighter with age.

No. 136. MONTRESOR. Bright carmine red, large flower, striking color

No. 137. PRINCE OF ORANGE. Beautiful orange, lighter to the edge

No. 138. SABRINIA. Rich golder bronze, on strong' stem

\section{REMBRANDT TULIPS}

These are cousins of the darwins; they rival the darwins in height. Fine for border's. Plant during October or November.

Doz.

.75

No. 140. APPOLLO. Rosy lilac and white, striped dull crimson

No. 142. LA COQUETTE. Lilac and, white striped almost black

No. 143. QUASIMODO. White feathered carmine, very large

No. 144. NIXED. In the above and many other colors

\section{DOUBLE LATE TULIPS}

No. 146. BLUE FLAG. Large flower on a long stem

Doz.

.85

No. 147. BELLE ALLIANCE. Striped pink, very double

No. 148. YELLOW ROSE. Pure yellow, very nice flower

\section{SINGLE NARCISSI OR DAFFODILS}

Should be planted not later than October. They are quite hardy and will bloom just before the early tulips come out, or slightly laier than the hyacinths. Narcissi should not be planted in regular beds or borders. A much better effect will be had by scattering them in the lawn or planting in clumps of irregular shape. Most varieties are good for forcing, though only the varieties marked G .F. I. should be chosen for this work. Only the leaders are offered here, all big plump mother bulbs.

No. 150. AJAX PRINCEPS. One of the earliest for forcing or out-

Doz. doors, broad primrose perianth, with orange yellow trumpet G. F. I.

No. 151. AJAX MAD. DE GRAFF. Perianth white cap primrose changing to pure white, a very fine flower.

No. 152. AJAX KING ALFRED. Extra. One of the finest and largest shaped trumpets, golden yellow

No. 153. AJAX EMPEROR. Deep primrose perianth, with yellow trumnet. One of the largest and most free blooming. G. F. I...

No. 154. BARRI CONSPICIUS. Primrose perianth, with orange yellow cup edged red, very early and stately. G. F. I.

No. 155. BARRI LADY MOORE. (new). Extra fine for forcing perianth ivory white, cup canary yellow, scarlet orange border fine for cut flowers G. F. I., each $\$ 0.35$

No. 156. BICOLOR EMPRESS. Rich yellow trumpet, pure white perianth 
No. 157. BICOLOR VICTORIA. Bold erect flower with creamy white

No. 158. PETICUS ORNATUS. White perianth and scarlet eye, fine

Doz. for naturalizing G. F. I.

2.00

15.00

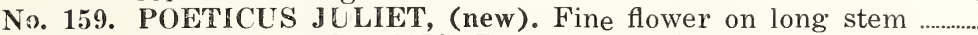

No. 160. LEEDSII MRS. LANGTRY. White perianth with large white cup edged bright yellow

$1.35 \quad 10.00$

$1.35 \quad 10.00$

GOLDEN SPUR. The entire flower is of a pleasing yellow

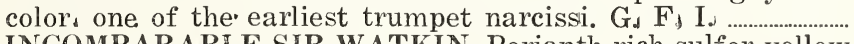

10.00

No. 161.

No. 162. INCOMPARABLE SIR WATKIN. Perianth rich sulfer yellow with bright orange cup, fine for outdoors. G. F. I.

2.00

15.00

No. 163. POETAS ASPACIA. Pure white yellow cup, long stem ............

No. 164. POETAZ ELVIRA. Pure yellow, with goldn yellow cup :.............

No. 165. POETAZ IDEAL. Perianth white cup dark orange

$2.00 \quad 15.00$

$1.35 \quad 10.00$

$1.35 \quad 10.00$

$1.35 \quad 10.00$

$1.35 \quad 10.00$

No. 166. POETAZ IRENE. Sulphur white orange cup, fine cutflower ......

No. 167. PUETAZ JAUNE A MERVEILLE. Yellow with golden cup...

No. 168. POETAZ GRAND PRIMO. Large yellow flower

$1.50 \quad 11.00$

$1.35 \quad 10.00$

No. 169. POETAZ LAURENS KOSTER. Early white, yellow cup edged orange, very fine for cut flower

No. 170. MIXED of many shades, for outdoor work only

$1.35 \quad 10.00$

$1.00 \quad 7.00$

\section{ISOUBLE NARCISSI}

No, 171. ALBO PLENO ODORATO. Very late, large well filled flower, one of the best pure white Narscissi

Doz.

100

$1.35 \quad 10.00$

No. 172. INCOMPARABLE. (Butter and Eggs). Large flower of a sulphury yellow color, fine for borders and cut flowers .......................

No. 173. VON SION. Rich golden yellow, fine for border, G. F. I. .......

$1.35 \quad 10.00$

$2.00 \quad 15.00$

No. 174. MIXED of many shades, for outdoor work ………........................... $1.35 \quad 10.00$

\section{CROCUS}

Thesa littla fellows are the first to blossom in the spring; long before the daffodils or hyacinths are awake to the fact thai Winter has gone and Spring is here these little flowers thrust their lovely, heads, through the snow and fairly shout at us that spring is once more in the land. They will grow anywhere, plant them anywhere you please but plant lots of them. Plant in October about' 3 inches deep, and as close as you please.

No. 175. BARON VON BRUNOW. Purplish mauve ....................................... .45 2.50

No. 176. LOTHAIR. White with blue stripes .................................................... $\quad .45 \quad 2.50$

No. 177. MAMMOTH YELLOW. One of the largest and finest yellow... $\quad .45 \quad 2.50$

No. 178. MONT BLANC. Almost pure white ....................................................... $\quad .45 \quad 2.50$

No. 179. PURPUREA GRANDIFLORA. One of the best purple ............ $\quad .50 \quad 2.75$

No. 180. SILVER CLOTH. Large white ........................................................... $\quad .45 \quad 2.50$

No. 181. SIR WALTER SCOTT. White with pale yellow stripe ............. $\quad .45 \quad 2.50$

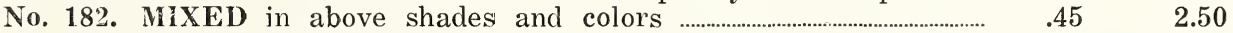

No. 183. COMPLETE SPRING GARDEN COLLECTION. Consisting of 25 Early tulips, 25 Mayflowers. 25 Dorw ns, ¿5 $\mathrm{l}$ r eders, 25 Narci s', 25 Crocus and 10 Hyacinths. 160 bulbs in all, for $\$ 10.00$. Purchased seperately these would cost about $\$ 13.00$. Exactly 35 different' colors in this collection.

\section{MISCELLANEOUS BULBS}

No. 184. GALANTHUS (snowdrops). Pure white, earliest spring flower

Doz.

100

No. 185. CHIONODOXA (glory of the snow). Luciliae, clear blue ......

No. 186. SCILLA STBERICA. Fine blue, very blue

$\$ 0.50$

$\$ 3.00$

.50

.50

No. 187. SCILLA CAMPANULATA, blue Mayflowering

No. 188. SCILLA CAMPANULATA. Rose Mayflowering

No. 189. SCILLA CAMPANULATA. White Mayflowering"

No. 190. SCILLA ITALICA. Blue large truss

No. 191. MUSCARI (Grape Hyacinth). Heavenly blue

No. 192. AZUREUM. Blue. Very fine for border work

No. 193. CORELEUM. Blue 


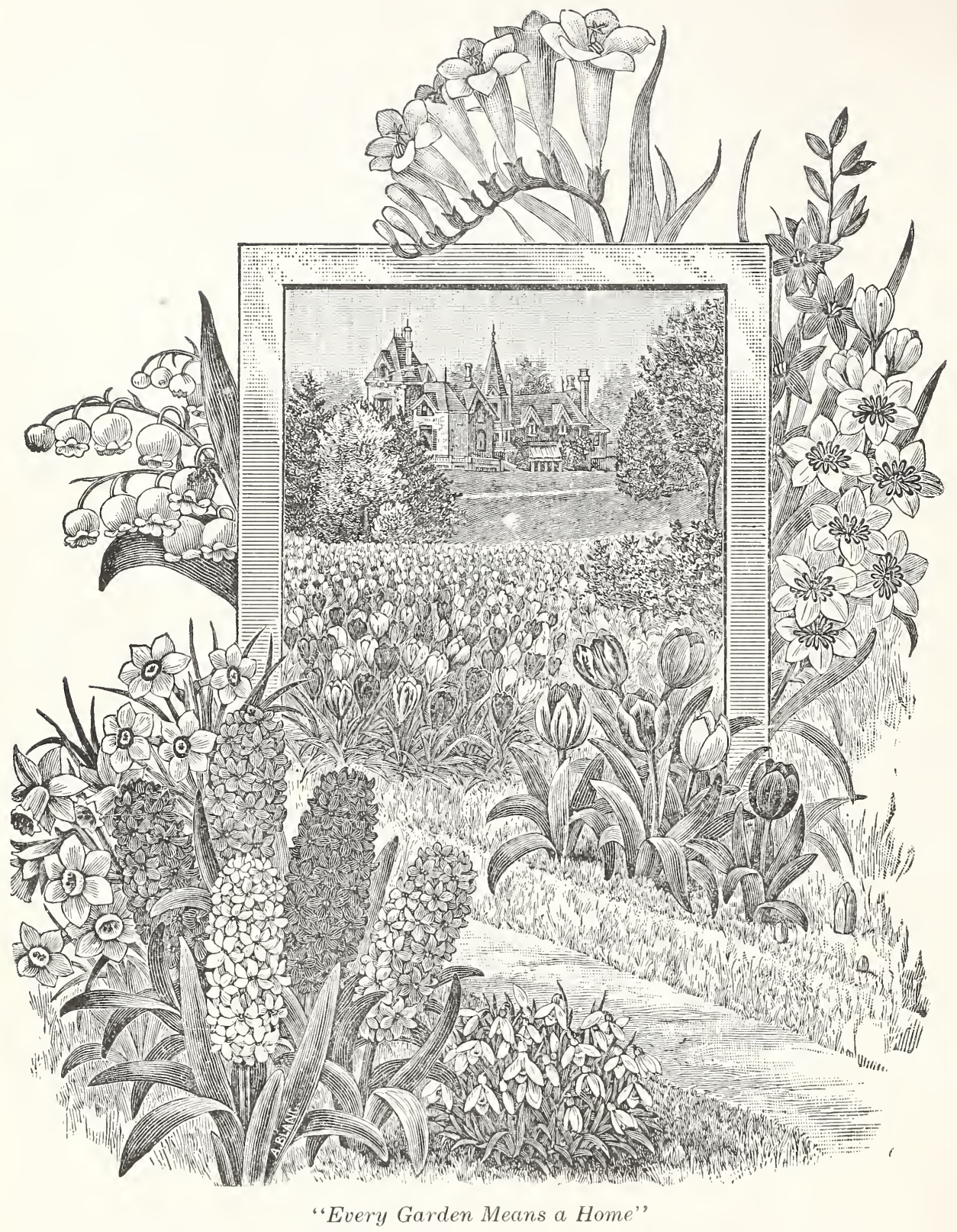

\section{Michigan Bulb Propagating Co.}

"Oldest Growers of Dutch Buibs in America",

Byron Center, Michigan, U. S. A.

Established 1914 